\title{
Prevalence and antibiotic resistance of Aeromonas hydrophila and Staphylococcus aureus isolated from seafood in Egypt
}

Basma M. Elkamouny, Rasha M. Elkenany1*, Gamal A. Younis

Department of Bacteriology, Mycology, and Immunology, Faculty of Veterinary Medicine, Mansoura University, 35516 Mansoura, Egypt

\section{ARTICLE HISTORY}

Received: 02.09.2020

Revised: 25.10 .2020

Accepted: 26.10 .2020

Address correspondences to Rasha M. Elkenany, PhD; Tel: +201090226696; E-mail:

dr_rashavet22@yahoo.com

\section{ABSTRACT}

\begin{abstract}
Objective: To investigate prevalence of Aeromonas. hydrophila and Staphylococcus aureus in seafood, and to detect the consistent virulence genes as well as to assess the antimicrobial susceptibility. Design: Observational study.

Samples: 280 marketed seafood samples (178 shrimp, 54 oysters, 26 crabs, 18 squid, and 4 octopuses). Procedures: Isolation and identification of Aeromonas hydrophila and Staphylococcus aureus wer performed using conventional methods. The identified isolates were examined for virulence genes (aer an hly genes for $A$. hydrophila as well as nuc and sea genes for $S$. aureus) as well as for antimicrobi: susceptibility.

Results: A. hydrophila was isolated from 40 of the 280 seafood samples (14.3\%), with the highest prevalence $(22.2 \%)$ in oyster samples, whereas S. aureus occurred in 50 samples $(17.9 \%)$ with the highest prevalence $(20.2 \%)$ in shrimp samples. Moreover, aer and hly genes were detected in all isolates of $A$. hydrophila, and thermonuclease (nuc) gene was detected in all tested $S$. aureus strains, whereas staphylococcal enterotoxin A (sea) gene was found in only $44 \%$ of $S$. aureus strains. A. hydrophila strains were absolutely resistant to amoxicillin (100\%), followed by ceftriaxone (80\%), chloramphenicol (77.5\%), trimethoprim-sulfamethoxazole (65\%), and tetracycline (55\%), whereas S. aureus strains showed high resistance to penicillin (86\%), followed by amoxicillin-clavulanic acid (72\%), and trimethoprimsulfamethoxazole (58\%). Multidrug resistance (MDR) to more than two classes of antibiotics was found in $77.5 \%$ (31/40) of $A$. hydrophila strains and $66 \%$ (28/50) of S. aureus isolates.

Conclusion and clinical relevance: Our data highlights the importance of awareness of virulent strains $c$ MDR A. hydrophila and S. aureus strains of seafood samples in Egypt. Consequently, the continuou surveillance of these bacteria in seafood with a strong focus on their antibiotic resistance characteristic should be considered in further studies.
\end{abstract}

Keywords: Aeromonas hydrophila; Antibiotic resistance; Seafood; Staphylococcus aureus.

\section{INTRODUCTION}

Seafood is an essential component of community nutrition, however the consumption of contaminated seafood often causes gastrointestinal diseases in humans [1] and leads to a significant number of outbreaks in many countries[2]Aquaculture farms and seafood are important reservoirs of many of the pathogenic bacteria, seafood hosts bacteria due to its flesh texture and their habitat which is loaded by microbes[3].

Aeromonas is considered a universal and causative agent of outbreaks primarily in aquaculture, and $A$. hydrophila and A. salmonicida in particular are common causative agents of ulcerative and hemorrhagic skin ulcers. Conditions such as stress, poor sanitation, and nutritional deficiencies favor these infections[4] The distribution of $A$. hydrophila is worldwide and it has been isolated from various sources including meat, fish, and shellfish. It can lead to infections in humans ranging from gastroenteritis to grave septicemia[5]A. hydrophila can tolerate a wide range of temperatures from freezing to boiling[6].

S. aureus ranks third among the leading etiological agents of reported food-borne illnesses worldwide[7] The frequent occurrence of staphylococcal food poisoning is attributed to human carriers, due to unhygienic food handling. Hence, the control of $S$. aureus depends on the implementation of proper hygiene measures and protocols[8]S. aureus has been detected in aquatic food products in many countries and presents a potential risk factor for consumers[9].

The pathogenicity of $A$. hydrophila comprises various virulence factors, including cytotoxic, hemolytic, and enterotoxic activities[10]Aerolysin, produced by some $A$. hydrophila strains is an extracellular, soluble, hydrophilic protein exhibiting both hemolytic and cytolytic properties and leading to diarrhea in humans [11]Aerolysin binds to specific glycoprotein receptors on the surface of eukaryotic cells before inserting into the lipid bilayer and forming holes. The hole-forming aerolysin toxin crosses the inner bacterial membrane as a preprotoxin containing a signal peptide which is removed cotranslationally. Hemolysins produced by $A$. hydrophila have a linear relationship with gastroenteritis in humans[12]Detection of virulence genes, particularly aerolysin (aer) and hemolysin ( $h / y)$ genes, by polymerase chain reaction (PCR) assay is an accepted approach to identify pathogenic strains of $A$. hydrophila[13]. 
S. aureus produces thermonuclease, many types of staphylococcal enterotoxins (SES) and SE-like toxins. Thermonuclease is an exoenzyme catalyzing the hydrolysis of DNA and RNA. The recognition of nuc gene encoding thermonuclease was useful to improve $S$. aureus detection from different food sources[14]. In some areas of the world, food poisoning outbreaks are frequently associated with SEs [15]. SEA is the most frequently isolated enterotoxin among SFD outbreaks in France, Japan and UK[16].

Antibiotics are widely used in aquaculture to systemically deal with diseased fish as well as to promote growth and enhance production by reducing mortalities[17] Multidrugresistant (MDR) strains of $A$. hydrophila, (mainly resistant to $\beta$-lactam antibiotics) have emerged and been isolated in a number of different regions across the world[4].

S. aureus strains have a high capacity to develop antibiotic resistance, by different routes as genetic mutations and horizontal gene transfer from an external source [18]. The most abundant enzyme produced by $S$. aureus after exposure to $\beta$-lactam antibiotics is $\beta$-lactamase[19].

The present study aimed to investigate the prevalence of virulent and multidrug-resistant strains of $A$. hydrophila and $S$. aureus that may be considered emerging pathogens in seafood in Egypt.

\section{MATERIALS AND METHODS}

\subsection{Sample collection}

A total of 280 marketed seafood samples [178 shrimp (caridea), 54 oysters (Ostrea edulis), 26 crabs (brachyuran), 18 squid (teuthida), 4 octopuses (octopoda)] were randomly and aseptically collected from 10 different retail markets in Mansoura city, Egypt, during the period from March to September 2018. The samples were packed in an ice box and transported to the laboratory for analysis of pathogenic bacteria.

\subsection{Bacteriological analysis}

For the isolation of $A$. hydrophila, samples were cut by sterilized scalpel, dipped into screw cap bottles containing alkaline peptone water and incubated at $35^{\circ} \mathrm{C}$ for $18 \mathrm{~h}$ and then a loopful was streaked onto sheep blood agar with 10 $\mathrm{\mu g} / \mathrm{ml}$ ampicillin (ASBA) and incubated for 18-24 $\mathrm{h}$ at $35^{\circ} \mathrm{C}[20]$.

For the isolation of $S$. aureus, samples were cut by sterilized scalpel, dipped into screw cap bottles containing tryptic soy broth (TSB, Oxoid, Basingstoke, UK) and incubated at $37^{\circ} \mathrm{C}$ for $24 \mathrm{~h}$. The overnight-inoculated broth was streaked on Baird-Parker agar (BPA, Oxoid, Basingstoke, UK) with egg yolk tellurite (Oxoid, Basingstoke, UK). The presumptive colonies of $A$. hydrophila and $S$. aureus were morphologically and biochemically identified [21, 22].

2.3. Molecular determination of virulence-associated genes in A. hydrophila and S. aureus isolates
Conventional PCR was performed to investigate the virulence determinants using oligonucleotide primers including the genes encoding aer and hly in A. hydrophila isolates as well as the genes encoding thermonuclease (nuc) and staphylococcal enterotoxin A (sea) in S. aureus isolates. Briefly, DNA of $A$. hydrophila and S. aureus was extracted by boiling according to Yousr et al. [23] and [24] respectively. The amplification of DNA was achieved using oligonucleotides primers and specific cyclic conditions as illustrated in Table 1. The PCR assay was conducted using an Applied Biosystem, 2720 Thermal Cycler (USA). The $25 \mu \mathrm{l}$ reaction mixture comprised $12.5 \mu \mathrm{l}$ of $2 \times P C R$ master mix (Promega, Madison, USA), $1 \mu$ l of forward and $1 \mu$ l of reverse primer (Metabion, Germany), $4.5 \mu$ l of PCR-grade water, and $6 \mu \mathrm{l}$ of the DNA template under investigation. The PCRamplified products were separated by electrophoresis in 1.5\% agarose gel (Lonza Rockland, ME, USA). Gels were visualized and photographed using a gel documentation system (Cleaver Scientific Ltd., USA).

\subsection{Antibiotic susceptibility testing}

Bacterial isolates of either A. hydrophila or S. aureus were examined for their susceptibility to 12 different antibiotics (Oxoid, Basingstoke, UK) on Mueller-Hinton agar (Oxoid, Basingstoke, UK) using the disk diffusion method recommended by the Clinical and Laboratory Standards Institute (CLSI) (2014). The susceptibility of all isolates was tested against ciprofloxacin (CIP, $5 \mu \mathrm{g}$ ), trimethoprimsulfamethoxazole (SXT, $25 \mu \mathrm{g})$, gentamicin (CN, $10 \mu \mathrm{g}$ ), chloramphenicol (C, $30 \mu \mathrm{g})$, and tetracycline (TE, $30 \mu \mathrm{g})$. Additionally, the susceptibility of the $A$. hydrophila isolates was tested against the following antibiotic disks: nitrofurantoin $(F, 15 \mu \mathrm{g})$, amoxicillin ( $A X, 30 \mu \mathrm{g})$, and ceftriaxone (CRO, $30 \mu \mathrm{g})$. Meanwhile, $S$. aureus isolates were tested against penicillin $(P, 10 \mu \mathrm{g})$, clarithromycin (CLR, 15 $\mu \mathrm{g})$, erythromycin (E, $15 \mu \mathrm{g})$, and amoxicillin-clavulanic acid (AMC, $30 \mu \mathrm{g}$ ). The tested antibiotics were selected according to their clinical use in both human and veterinary medicine. The diameter of the inhibition zone was measured and interpreted in accordance with the guidelines of the CLSI (2014). Strains resistant to more than two classes of antibiotics were considered multidrug-resistant (MDR) strains.

\section{RESULTS}

\subsection{Occurrence of A. hydrophila and S. aureus in seafood}

A. hydrophila was isolated from 40 of the 280 seafood samples (14.3\%), whereas $S$. aureus was isolated from 50 samples (17.9\%) (Table 2). Both A. hydrophila and S. aureus isolates were identified by morphological and biochemical examinations. The highest prevalence of $A$. hydrophila strains was detected in oyster samples $(22.2 \%, 12 / 54)$ followed by crab $(15.4 \%, 4 / 26)$, shrimp $(12.4 \%, 22 / 178)$, squid $(11.1 \%$, $2 / 18$ ) and octopus $(0 / 4,0 \%)$, whereas the highest prevalence of $S$. aureus strains was found in shrimp samples $(20.2 \%$, $36 / 178)$ followed by crab $(15.4 \%, 4 / 26)$, oyster $(14.8 \%, 8 / 54)$, squid $(11.1 \%, 2 / 18)$ and octopus $(0 / 4,0 \%)$. 
Table 1. Oligonucleotide primers used in this study.

\begin{tabular}{|c|c|c|c|c|}
\hline Target gene & Primer sequences & Annealing & Amplicon size (bp) & References \\
\hline hly & $\begin{array}{l}\text { 5'-CTATGAAAAAACTAAAAATAACTG-3' } \\
5^{\prime} \text {-CAGTATAAGTGGGGAAATGGAAAG-3' }\end{array}$ & $55^{\circ} \mathrm{C}$ & 1500 & [23] \\
\hline aer & $\begin{array}{l}\text { 5' CACAGCCAATATGTCGGTGAAG3' } \\
\text { 5' GTCACCTTCTCGCTCAGGC3' }\end{array}$ & $52{ }^{\circ} \mathrm{C}$ & 326 & [10] \\
\hline nuc & $\begin{array}{l}\text { 5' GCGATTGATGGTGATACGGTT3' } \\
\text { 5' AGCCAAGCCTTGACGAACTAAAGC3' }\end{array}$ & $55^{\circ} \mathrm{C}$ & 267 & [54] \\
\hline sea & $\begin{array}{l}\text { 5' GGTTATCAATGTGCGGGTGG3' } \\
\text { 5' CGGCACTIIITCTCTTCGG3' }\end{array}$ & $57^{\circ} \mathrm{C}$ & 102 & [55] \\
\hline
\end{tabular}

Table 3. Antibiotic resistant strains of Aeromonas hydrophila $(n=40)$ and Staphylococccus aureus $(n=50)$ isolated from seafood.

\begin{tabular}{|c|c|c|c|c|c|c|c|}
\hline \multirow{2}{*}{ Antibiotic class } & \multirow{2}{*}{ Antibiotic disk } & \multicolumn{2}{|c|}{ A. hydrophila } & \multicolumn{3}{|c|}{ S. aureus } & \multirow[b]{2}{*}{ S } \\
\hline & & $\mathbf{R}$ & 1 & $\mathbf{S}$ & $\mathbf{R}$ & $\mathbf{I}$ & \\
\hline \multirow{3}{*}{$\beta$-Lactams } & Amoxicillin & 40 (100\%) & 0 & 0 & - & - & - \\
\hline & Amoxicillin-clavulinic acid & - & - & - & $36(72 \%)$ & 0 & $14(28 \%)$ \\
\hline & Penicillin & - & - & - & $43(86 \%)$ & 0 & $7(14 \%)$ \\
\hline Cephalosporins & Ceftriaxone & $32(80 \%)$ & $8(20 \%)$ & 0 & - & - & - \\
\hline Phenicols & Chloramphenicol & $31(77.5 \%)$ & $9(22.5 \%)$ & 0 & $7(14 \%)$ & $21(42 \%)$ & $22(44 \%)$ \\
\hline Sulphonamides & $\begin{array}{l}\text { Trimethoprim- } \\
\text { Sulfamethoxazole }\end{array}$ & $26(65 \%)$ & $14(35 \%)$ & 0 & $29(58 \%)$ & 0 & $21(42 \%)$ \\
\hline Tetracyclines & Tetracycline & $22(55 \%)$ & $4(10 \%)$ & $14(35 \%)$ & 7 (14\%) & $7(14 \%)$ & $36(72 \%)$ \\
\hline Fluoroquinolones & Ciprofloxacin & $4(10 \%)$ & $22(55 \%)$ & $14(35 \%)$ & $26(52 \%)$ & 0 & $24(48 \%)$ \\
\hline Macrolides & Erythromycin & - & - & - & $18(36 \%)$ & $28(56 \%)$ & $4(8 \%)$ \\
\hline \multirow{2}{*}{ Aminoglycosides } & Gentamicin & $14(35 \%)$ & $4(10 \%)$ & 22 (55\%) & 7 (14\%) & 0 & $43(86 \%)$ \\
\hline & Nitrofurantoin & $10(25 \%)$ & $24(60 \%)$ & $6(15 \%)$ & - & - & - \\
\hline
\end{tabular}

Table 2. Occurrence of Aeromonas hydrophila and Staphylococcus aureus strains in seafood.

\begin{tabular}{|c|c|c|c|}
\hline Samples & $\begin{array}{l}\text { No. of } \\
\text { samples }\end{array}$ & $\begin{array}{l}\text { No. of } A \text {. } \\
\text { hydrophila isolates } \\
(\%)\end{array}$ & $\begin{array}{l}\text { No. of S. } \\
\text { aureus } \\
\text { isolates (\%) }\end{array}$ \\
\hline Shrimp & 178 & $22(12.4)$ & $36(20.2)$ \\
\hline Oysters & 54 & $12(22.2)$ & $8(14.8)$ \\
\hline Crabs & 26 & $4(15.4)$ & $4(15.4)$ \\
\hline Squid & 18 & 2 (11.1) & $2(11.1)$ \\
\hline Octopus & 4 & $0(0)$ & $0(0)$ \\
\hline Total & 280 & $40(14.3)$ & 50 (17.9) \\
\hline
\end{tabular}

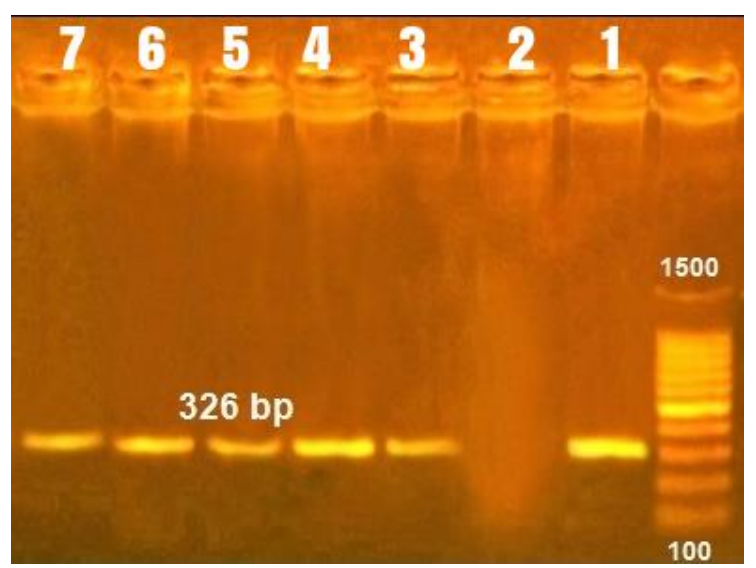

Figure 1. Representative agarose gel electrophoresis of aerolysin gene amplification (326 bp) of Aeromonas hydrophila isolates from seafood. Lane (1): control positive. Lane (2): control negative. Lanes (3-7): positive samples.

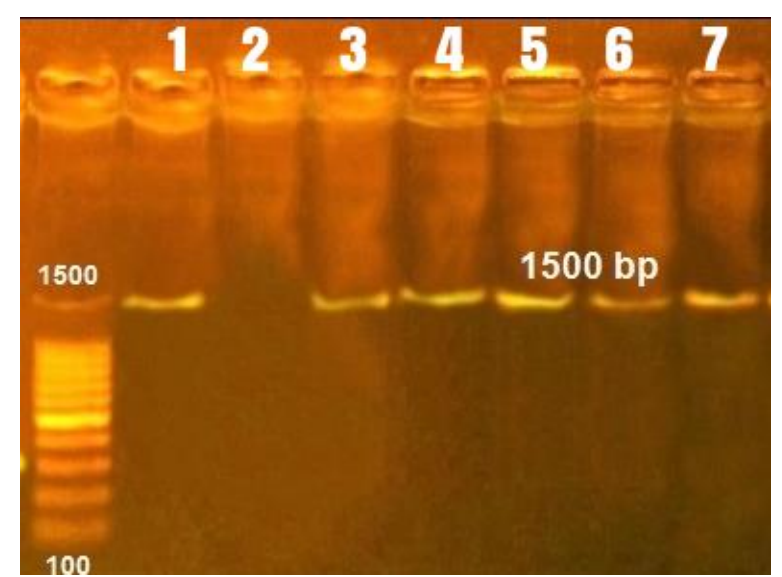

Figure 2. Representative agarose gel electrophoresis of hemolysin gene (1589 bp) of Aeromonas hydrophila isolates from seafood. Lane (1): positive control. Lane (2): negative control. Lanes (3-7): positive samples.

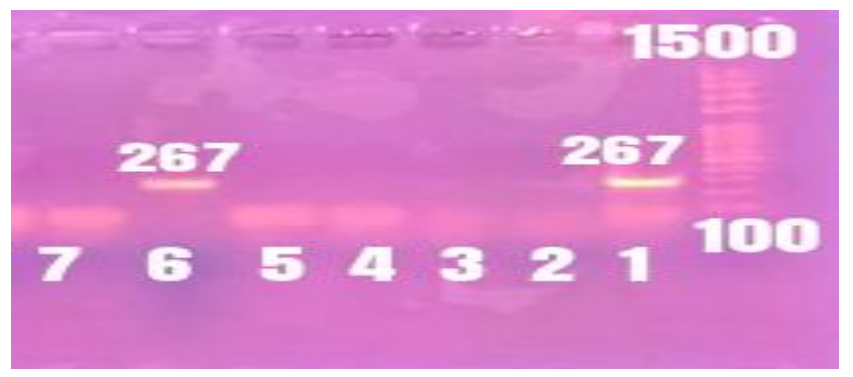

Figure 3. Representative agarose gel electrophoresis of thermonuclease gene (267 bp) of Staphylococcus aureus isolates from seafood. Lane (1): positive control. Lane (2): negative control. Lanes (3-5,7): negative samples. Lane (6): positive samples. 
3.2. Determination of virulence-associated genes in $A$. hydrophila and S. aureus isolates

A. hydrophila isolates were screened for the existence of virulence genes (aer and $h / y$ ). Both aer and hly genes were detected in all tested strains (100\%, 40/40) (Figure 1, 2). Additionally, S. aureus strains were tested for the presence of virulence genes (nuc and sea). The nuc gene was found in all tested strains; whereas the sea gene was found in only $44 \%$ $(22 / 50)$ of $S$. aureus strains (Figure 3,4$)$.

\subsection{Antibiotic susceptibility results}

Antibiotic susceptibility testing was performed on $A$. hydrophila and $S$. aureus strains isolated from seafood. $A$. hydrophila isolates were absolutely resistant to AX (100\%) and highly resistant to CRO (80\%), C (77.5\%), SXT (65\%), TE (55\%), and CN (35\%). The lowest resistance was noted for CIP $(10 \%)$ and $F(25 \%)$.

S. aureus strains showed high resistance to $\mathrm{P}(86 \%)$, followed by AMC (72\%), SXT (58\%), and CIP (52\%). Additionally, S. aureus strains showed high sensitivity to $\mathrm{CN}$ (86\%), followed by TE (72\%), CLR (58\%), and C (44\%) (Table 3). MDR to more than two classes of antibiotics was determined in $77.5 \%$ of $A$. hydrophila strains (31/40) and $66 \%$ of $S$. aureus isolates $(28 / 50)$.

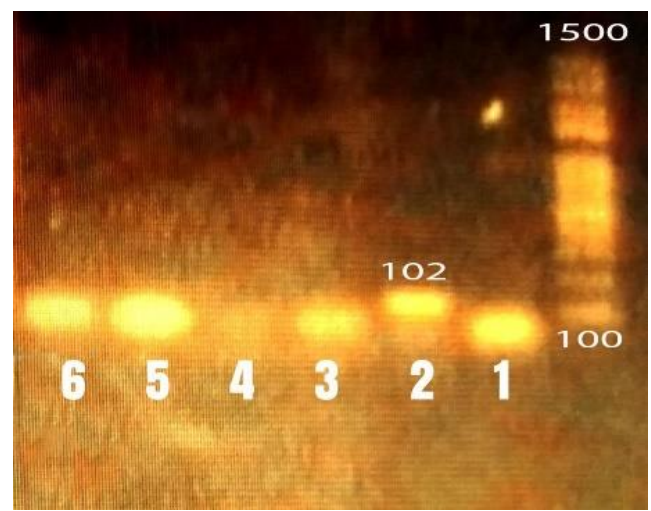

Figure 4. Representative agarose gel electrophoresis of staphylococcal enterotoxin A gene (102 bp) of Staphylococcus aureus isolates from seafood. Lane (1): negative control. Lane (2): positive sample. Lanes: (3-6): negative samples.

\section{DISCUSSION}

Seafood is a rich source of proteins, unsaturated fatty acids, and vitamins. However, due to the texture of its flesh and its microbe-filled habitat, seafood also represents a highly significant host for many pathogenic bacteria [3]. Pathogenic bacteria may be present in high numbers in food without producing noticeable changes in odor, taste, or features[25]. Therefore, detection of these bacteria in seafood is vital, particularly A. hydrophila and S. aureus which are associated with gastrointestinal infections in humans. In this study, the prevalence of $A$. hyrophila in seafood was found to be $14.2 \%$ with the highest prevalence in oyster samples $(22.2 \%)$, followed by crab (15.4\%), shrimp (12.4\%), and squid (11.1\%). This result was in line with those previously reported by Ullmann et al. [26] (14.2\%) in
Germany, Rahimi et al. [27] (13.5\%) in Iran, and Hussain et al. [28] (19\%) in India. In contrast, a low prevalence of $A$. hydrophila (5.71\%) was reported in Turkey, with the highest occurrence (15\%) found in shrimp [29], whereas a high prevalence of 58\% was detected by Niamah [30] in Iraq, and $25 \%$ was reported by [31] in Egypt. The prevalence of $A$. hydrophila in seafood indicates poor hygienic practices.

S. aureus likewise presents a potential risk to consumers of aquatic food products [9] in this study, the prevalence of $S$. aureus was found to be $17.8 \%$ with the highest prevalence in shrimp samples (20.2\%). These results were consistent with [32] (17\%) in Spain, Kumar et al. [33] (15.78\%) in India, and Othman et al. [34](15\%) in Malaysia. However, a higher prevalence was reported by[35] (37.2\%) in China with the highest prevalence in freshwater fish (52.1\%). Soltan Dallal et al. [36]in Iran also recorded a high prevalence (28\%). A lower prevalence for $S$. aureus in seafood was generally found in other recently reported studies. In Switzerland, Boss et al. [37]recorded $9 \%$ prevalence with the highest rate in shrimp (18\%), and, in Turkey, Mus et al. [38]found a $6 \%$ prevalence in seafood with the highest prevalence in shrimp (20\%). Additionally, in Libya, Naas et al. [39]detected a $5.3 \%$ prevalence in seafood samples. Overall, these results indicated that seafood from retail markets in the study localities presented a potential source of infection for human consumers.

An investigation into virulence-associated genes was performed in order to detect virulent strains isolated from seafood. In this study, aer and hly genes were detected in all the tested A. hydrophila strains (100\%). Similarly, Yousr et al. [23] and Niamah [30] identified the aer gene in all their $A$. hydrophila isolates from seafood and shrimp. The hly gene has also previously been detected in all $A$. hydrophila isolates from fish and shrimp and squid[28]. Moreover, in Egypt, all $A$. hydrophila strains isolated from food samples tested positive for both aer and hly genes [40].

The pathogenicity of S.aureus in cases of food poisoning is associated with the ability of some strains to produce enterotoxins [41]. Thus, the present study aimed to detect one of the most common staphylococcal enterotoxins in aquaculture, the sea gene, by PCR assay. In the current investigation, the sea gene was detected in $44 \%$ of S.aureus strains. This result was compatible with the $45.2 \%$ that Arfatahery et al. [42] detected in S. aureus strains isolated from fish and shrimp samples. SoltanDallal et al. [36] and Rong et al. [35], however, detected lower prevalence of sea gene at $39.3 \%$ and $22.7 \%$, respectively.

Although the use of antibiotics might promote growth and increase productivity in aquacultures, there is an emergent concern surrounding antibiotic resistance selection as a result of the wide use of antibiotics, especially when used inadequately or in overdose [43]. In this investigation, the isolates were tested against different classes of antibiotics to evaluate the antibiotic efficacy in the treatment of aquaborne microbes $A$. hydrophila and $S$. aureus. The results showed that $A$. hydrophila strains were completely resistant 
to AX (100\%) and highly resistant to CRO (80\%), C (77.5\%), SXT $(65 \%)$, TE $(55 \%)$, and CN (35\%). These results confirm the previously reported high resistance of $A$. hydrophila to a wide range of the $\beta$-lactams antibiotics family, as well as SXT, and TE [44-46]. In contrast, Stratev et al. [47] reported no observed resistance to TE and SXT in A. hydrophila strains. Contradictory to our findings, high sensitivity to $C$ was observed in a previous study [46, 48], whereas Stratev et al. [47]showed absolute resistance to C. Findings by Saavedra et al. [49] supported the existence of $\mathrm{CN}$ resistant strains, with a frequency of $31 \%$.

S. aureus is notorious for its MDR and, in the present study; S. aureus isolates showed resistance to $\mathrm{P}, \mathrm{Ox}(86 \%$ each), AMC (72\%), SXT (58\%), CIP (52\%), and E (36\%). The antibiotic resistance of $S$. aureus to extended-spectrum $P$, AMC, SXT, and E support the findings of other recent studies $[35,42,50]$. However, [39] reported a high sensitivity in $S$. aureus strains isolated from shrimp in Libya to SXT and AMC as well as to CIP and C.

MDR bacteria complicate the treatment of human and animal infections. Unfortunately, our results revealed MDR against three or more antibiotics in $77.5 \%$ of $A$. hydrophila isolates. This result was compatible with Kaskhedikar and Chhabra [51] who found $100 \%$ of $A$. hydrophila isolated from fish to have MDR. Moreover, the current study found that $66 \%$ of $S$. aureus strains displayed MDR. In China, Rong et al. [35] detected MDR in $90.6 \%$ of $S$. aureus strains.

The development of multidrug-resistant strains is associated with the over-exposure to either bactericidal or bacteriostatic antibiotics used for the prevention and treatment of infections in aquaculture farming $[52,53]$. The higher MDR strains observed in the present study might be attributed to the widespread use of antibiotics in the study locality in Egypt, as well as the indiscriminate use of antibiotics either at recommended doses or at subtherapeutic doses as feed additives to promote growth in developing countries. These findings have significant implications for public health.

\section{Conclusion}

In this research, the prevalence of virulent and MDR strains of $A$. hydrophila and $S$. aureus in seafood represents an important aspect of food safety and poses a zoonotic concern to public health in Egypt. Current data indicates poor hygienic practices, stress conditions during farming, contaminated additives, cross-contamination between seafood, and the indiscriminate use of antibiotics in fish farms have led to an increased prevalence of MDR strains worldwide. Consequently, this suggests that a suitable disease management and control strategy must be endorsed for fish farms, and treatment assays implemented to deal with antibiotic usage. Also, the continuous surveillance of these bacteria in seafood with a strong focus on their antibiotic resistance characteristics should be considered in further studies.

\section{Acknowledgement}

Department of Bacteriology, Mycology and Immunology, Faculty of Veterinary Medicine, Mansoura University, Egypt, supported this study.

\section{Conflict of interest statement}

No conflict of interest.

\section{Research Ethics Committee Permission}

The current research work is permitted to be executed according to standards of Research Ethics committee, Faculty of Veterinary Medicine, Mansoura University.

\section{Authors'contribution}

Gamal A. Younis designed the experiment and revised the manuscript. Gamal A. Younis, Rasha M. Elkenany supervised in carrying out the practical part. Rasha $M$. Elkenany shared in writing the paper and took the responsibility of correspondence to the journal. Basma $M$. Elkamouny collected samples and carried out the practical part. All authors approved the final version of the manuscript for publication.

\section{REFERENCES}

[1] Raghunath P, Acharya S, Bhanumathi A, Karunasagar I, Karunasagar I. Detection and molecular characterization of Vibrio parahaemolyticus isolated from seafood harvested along the southwest coast of India. Food Microbiology. 2008;25:824-30. https://doi.org/10.1016/j.fm.2008.04.002

[2] Solano R, Lafuente S, Sabate S, Tortajada C, García de Olalla P, Hernando AV, et al. Enterotoxin production by Staphylococcus aureus: An outbreak at a Barcelona sports club in July 2011. Food Control. 2013;33:114-8. https://doi.org/10.1016/j.foodcont.2013.01.014

[3] Khan MA, Khan S, Miyan K, Mubark M. Length-weight Relationships for Nine Freshwater Teleosts Collected from River Ganga, India. International Journal of Zoological Research. 2011;7:401-5. https://doi.org/10.3923/ijzr.2011.401.405

[4] Igbinosa IH, Igumbor EU, Aghdasi F, Tom M, Okoh Al. EmergingAeromonasSpecies Infections and Their Significance in Public Health. The Scientific World Journal. 2012;2012:1-13. https://doi.org/10.1100/2012/625023

[5] Janda JM, Abbott SL. The Genus Aeromonas: Taxonomy, Pathogenicity, and Infection. Clinical Microbiology Reviews. 2010;23:35-73. https://doi.org/10.1128/CMR.00039-09

[6] Abd-El-Malek AM. Incidence and virulence characteristics of Aeromonas spp. in fish. Veterinary World. 2017;10:34-7. https://doi.org/10.14202/vetworld.2017.34-37

[7] Park H-O, Kim C, Woo G, Park S, Lee D, Chang E, et al. Monitoring and trends analysis of food poisoning outbreaks occurred in recent years in Korea. J Food Hyg Saf. 2001;16:280-94.

[8] Kadariya J, Smith TC, Thapaliya D. Staphylococcus aureusand Staphylococcal Food-Borne Disease: An Ongoing Challenge in Public Health. BioMed Research International. 2014;2014:1-9. https://doi.org/10.1155/2014/827965

[9] Cho JI, Joo IS, Choi JH, Jung KH, Choi EJ, Son NR, et al. Distribution of Methicillin-resistant Staphylococcus aureus (MRSA) in RAW meat and fish samples in Korea. Food Science and Biotechnology. 2014;23:9991003. https://doi.org/10.1007/s10068-014-0135-z

[10] Singh V, Rathore G, Kapoor D, Mishra BN, Lakra WS. Detection of aerolysin gene in Aeromonas hydrophila isolated from fish and pond water. Indian Journal of Microbiology. 2008;48:453-8. https://doi.org/10.1007/s12088-008-0056-8

[11] Lior $\mathrm{H}$, Johnson W. Application of the polymerase chain reaction (PCR) to detection of the aerolysin gene in whole cell cultures of betahemolytic Aeromonas hydrophila. Experientia. 1991;47:421-4. 
[12] Soler L, Figueras MJ, Chac $\tilde{A}^{3} n$ MR, Vila J, Marco F, Martinez-Murcia AJ, et al. Potential virulence and antimicrobial susceptibility ofAeromonas popoffiirecovered from freshwater and seawater. FEMS Immunology \& Medical Microbiology. 2002;32:243-7. https://doi.org/10.1111/j.1574695X.2002.tb00560.x

[13] Wang G, Clark CG, Liu C, Pucknell C, Munro CK, Kruk TMAC, et al. Detection and Characterization of the Hemolysin Genes in Aeromonas hydrophila and Aeromonas sobria by Multiplex PCR. Journal of Clinical Microbiology.

2003;41:1048-54 https://doi.org/10.1128/JCM.41.3.1048-1054.2003

[14] Alarcon B, Vicedo B, Aznar R. PCR-based procedures for detection and quantification of Staphylococcus aureus and their application in food. Journal of Applied Microbiology. 2006;100:352-64. https://doi.org/10.1111/j.1365-2672.2005.02768.x

[15] Arfatahery N, Mirshafiey A, Abedimohtasab T, Zeinolabedinizamani M. Study of the prevalence of Staphylococcus aureus in marine and farmed shrimps in Iran aiming the future development of a prophylactic vaccine. Procedia in Vaccinology. 2015;9:44-9. https://doi.org/10.1016/j.provac.2015.05.008

[16] Argudín MÁ, Mendoza MC, Rodicio MR. Food Poisoning and Staphylococcus aureus Enterotoxins. Toxins. 2010;2:1751-73. https://doi.org/10.3390/toxins2071751

[17] Pridgeon J. Major bacterial diseases in aquaculture and their vaccine development. CAB Reviews: Perspectives in Agriculture, Veterinary Science, Nutrition and Natural Resources. 2012;7. https://doi.org/10.1079/PAVSNNR20127048

[18] Chambers HF, DeLeo FR. Waves of resistance: Staphylococcus aureus in the antibiotic era. Nature Reviews Microbiology. 2009;7:629-41. https://doi.org/10.1038/nrmicro2200

[19] Chopra I. Antibiotic resistance in Staphylococcus aureus: concerns, causes and cures. Expert Review of Anti-infective Therapy. 2003;1:4555. https://doi.org/10.1586/14787210.1.1.45

[20] Kay BA, Guerrero CE, Sack RB. Media for the isolation of Aeromonas hydrophila. Journal of Clinical Microbiology. 1985;22:888-90. https://doi.org/10.1128/JCM.22.5.888-890.1985

[21] Esteve C. Numerical Taxonomy of Aeromonadaceae and Vibrionaceae associated with Reared Fish and Surrounding Fresh and Brackish Water. Systematic and Applied Microbiology. 1995;18:391-402. https://doi.org/10.1016/S0723-2020(11)80432-7

[22] de Freitas Guimarães F, Nóbrega DB, Richini-Pereira VB, Marson PM, de Figueiredo Pantoja JC, Langoni $\mathrm{H}$. Enterotoxin genes in coagulasenegative and coagulase-positive staphylococci isolated from bovine milk. Journal of Dairy Science. 2013;96:2866-72. https://doi.org/10.3168/jds.2012-5864

[23] Yousr A, Napis S, Rusul G, Son R. Detection of aerolysin and hemolysin genes in Aeromonas spp. isolated from environmental and shellfish sources by polymerase chain reaction. ASEAN Food Journal. 2007;14:115.

[24] Alexopoulou K, Foka A, Petinaki E, Jelastopulu E, Dimitracopoulos G, Spiliopoulou I. Comparison of two commercial methods with PCR restriction fragment length polymorphism of the tuf gene in the identification of coagulase-negative staphylococci. Letters in Applied Microbiology. 2006;43:450-4. https://doi.org/10.1111/j.1472765X.2006.01964.x

[25] Ng SP, Tsui CO, Roberts D, Chau PY, Ng MH. Detection and serogroup differentiation of Salmonella spp. in food within 30 hours by enrichment-immunoassay with a T6 monoclonal antibody capture enzyme-linked immunosorbent assay. Applied and environmental microbiology. https://doi.org/10.1128/AEM.62.7.2294-2302.1996

[26] Ullmann D, Krause G, Knabner D, Weber H, Beutin L. Isolation and Characterization of Potentially Human Pathogenic, Cytotoxinproducing Aeromonas Strains from Retailed Seafood in Berlin, Germany. Journal of Veterinary Medicine Series B. 2005;52:82-7. https://doi.org/10.1111/j.1439-0450.2005.00820.x

[27] Rahimi E, Raissy M, Razzaghimanesh M, Ahmadi Dastgerdi A, Momeni Shahraki M. Occurrence of Aeromonas hydrophila in Fish, Shrimp, Lobster and Crab in Iran. Kafkas Universitesi Veteriner Fakultesi Dergisi. 2014. https://doi.org/10.9775/kvfd.2014.10892

[28] Hussain IA, Jeyasekaran G, Shakila RJ, Raj KT, Jeevithan E. Detection of hemolytic strains of Aeromonas hydrophila and A. sobria along with other Aeromonas spp. from fish and fishery products by multiplex PCR.
Journal of Food Science and Technology. 2013;51:401-7. https://doi.org/10.1007/s13197-013-1190-9

[29] Kahraman BB, Dumen E, Issa G, Kahraman T, Ikiz S. Incidence of Aeromonas hydrophila and Plesiomonas shigelloides in Seafoods. Turkish Journal of Fisheries and Aquatic Sciences. 2017;17:1309-12.

[30] Niamah AK. Detected of aero gene in Aeromonas hydrophila isolates from shrimp and peeled shrimp samples in local markets. The Journal of Microbiology, Biotechnology and Food Sciences. 2012;2:634.

[31] Abdel-Latef GK. Detection of aerolysin, hemolysin genes and antimicrobial susceptibility of Aeromonas hydrophila isolated from retail foods and human stool samples. Global Veterinaria, 14 (4). 2015:528-34.

[32] Gutiérrez D, Delgado S, Vázquez-Sánchez D, Martínez B, Cabo ML, Rodríguez A, et al. Incidence of Staphylococcus aureus and Analysis of Associated Bacterial Communities on Food Industry Surfaces. Applied and Environmental Microbiology. 2012;78:8547-54. https://doi.org/10.1128/AEM.02045-12

[33] Kumar LRG, Kasim AK, Lekshmi M, Nayak BB, Kumar S. Incidence of Methicillin-Resistant Staphylococci in Fresh Seafood. Advances in Microbiology. https://doi.org/10.4236/aim.2016.66039

[34] Othman BR, Kuan CH, Mohammed AS, Cheah YK, Tan CW, New CY, et al. Occurrence of methicillin-resistant Staphylococcus aureus in raw shellfish at retail markets in Malaysia and antibacterial efficacies of black seed (Nigella sativa) oil against MRSA. Food Control. 2018;90:32431. https://doi.org/10.1016/j.foodcont.2018.02.045

[35] Rong D, Wu Q, Xu M, Zhang J, Yu S. Prevalence, Virulence Genes, Antimicrobial Susceptibility, and Genetic Diversity of Staphylococcus aureus from Retail Aquatic Products in China. Frontiers in Microbiology. 2017;8. https://doi.org/10.3389/fmicb.2017.00714

[36] Soltan Dallal MM, Mazaheri Nezhad Fard R, Sharifi-Yazdi MK. Prevalence of sea, seb, tsst, and mecA Genes in Staphylococcus aureus Isolated from Shrimps Sold in Seafood Retailers in Tehran, Iran. Journal of Food Quality and Hazards Conrol. 2018;5:72-6. https://doi.org/10.29252/jfqhc.5.2.7

[37] Boss R, Overesch G, Baumgartner A. Antimicrobial Resistance of Escherichia coli, Enterococci, Pseudomonas aeruginosa, and Staphylococcus aureus from Raw Fish and Seafood Imported into Switzerland. Journal of Food Protection. 2016;79:1240-6. https://doi.org/10.4315/0362-028X.JFP-15-463

[38] Mus TE, Cetinkaya F, Celik U. Occurrence of Vibrio, Salmonella and Staphylococcus aureus in retail fresh fish, mussel and shrimp. Acta Veterinaria Brno. https://doi.org/10.2754/avb201483020075

[39] Naas HT, Edarhoby RA, Garbaj AM, Azwai SM, Abolghait SK, Gammoudi $\mathrm{FT}$, et al. Occurrence, characterization, and antibiogram of Staphylococcus aureus in meat, meat products, and some seafood from Libyan retail markets. Veterinary World. 2019;12:925-31. https://doi.org/10.14202/vetworld.2019.925-931

[40] El-Shabour FA, Amal F. Prevalence of Aeromonasmicroorganisms in frozen minced meat incharacterization of a typical strain of Alexandria governorate markets,. Kafrelsheikh VetMed J, . 2009;7:34-44.

[41] Le Loir Y, Baron F, Gautier M. Staphylococcus aureus and food poisoning. Genet Mol Res. 2003;2:63-76.

[42] Arfatahery N, Davoodabadi A, Abedimohtasab T. Characterization of Toxin Genes and Antimicrobial Susceptibility of Staphylococcus aureus Isolates in Fishery Products in Iran. Scientific Reports. 2016;6. https://doi.org/10.1038/srep34216

[43] Kolář M, Urbánek K, Látal T. Antibiotic selective pressure and development of bacterial resistance. International Journal of Antimicrobial Agents. 2001;17:357-63. https://doi.org/10.1016/S09248579(01)00317-X

[44] Chen P-L, Ko W-C, Wu C-J. Complexity of $\beta$-lactamases among clinical Aeromonas isolates and its clinical implications. Journal of Microbiology, Immunology and Infection. 2012;45:398-403. https://doi.org/10.1016/j.jmii.2012.08.008

[45] Lee SW, Wendy W. Antibiotic and heavy metal resistance of Aeromonas hydrophila and Edwardsiella tarda isolated from red hybrid tilapia (Oreochromis spp.) coinfected with motile aeromonas septicemia and edwardsiellosis. Veterinary World. 2017;10:803-7. https://doi.org/10.14202/vetworld.2017.803-807

[46] De Silva BCJ, Hossain S, Wimalasena SHMP, Pathirana HNKS, Heo G-J. Putative virulence traits and antibiogram profile of Aeromonas spp. 
isolated from frozen white-leg shrimp (Litopenaeus vannamei ) marketed in Korea. Journal of Food Safety. 2018;38:e12470. https://doi.org/10.1111/jfs.12470

[47] Stratev D, Odeyemi OA. Antimicrobial resistance of Aeromonas hydrophila isolated from different food sources: A mini-review. Journal of Infection and Public Health. 2016;9:535-44. https://doi.org/10.1016/j.jiph.2015.10.006

[48] Yano Y, Hamano K, Tsutsui I, Aue-umneoy D, Ban M, Satomi M. Occurrence, molecular characterization, and antimicrobial susceptibility of Aeromonas spp. in marine species of shrimps cultured at inland low salinity ponds. Food Microbiology. 2015;47:21-7. https://doi.org/10.1016/j.fm.2014.11.003

[49] Saavedra MJ, Guedes-Novais S, Alves A, Rema P, Tacão M, Correia A, et al. Resistance to $\beta$-lactam antibiotics in Aeromonas hydrophila isolated from rainbow trout (Onchorhynchus mykiss). International microbiology. 2004;7:207-11.

[50] Atwa El. Bacteriological Study of Fish Samples Collected from Different Markets in Some Egyptian Governorates and Antimicrobial Sensitivity of Isolates. International Journal of Current Microbiology and Applied Sciences.

2017;6:2765-76 https://doi.org/10.20546/ijcmas.2017.605.310

[51] Kaskhedikar M, Chhabra D. Multiple drug resistance in Aeromonas hydrophila isolates of fish. Food Microbiol. 2010;28:157-68.

[52] Cabello FC, Godfrey HP, Tomova A, Ivanova L, Dölz H, Millanao A, et al. Antimicrobial use in aquaculture re-examined: its relevance to antimicrobial resistance and to animal and human health. Environmental Microbiology. 2013;15:1917-42. https://doi.org/10.1111/1462-2920.12134

[53] Huang Y, Zhang L, Tiu L, Wang HH. Characterization of antibiotic resistance in commensal bacteria from an aquaculture ecosystem. Frontiers in Microbiology. 2015;6. https://doi.org/10.3389/fmicb.2015.00914

[54] Brakstad OG, Aasbakk K, Maeland JA. Detection of Staphylococcus aureus by polymerase chain reaction amplification of the nuc gene. Journal of Clinical Microbiology. 1992;30:1654-60. https://doi.org/10.1128/JCM.30.7.1654-1660.1992

[55] Mehrotra M, Wang G, Johnson WM. Multiplex PCR for Detection of Genes forStaphylococcus aureus Enterotoxins, Exfoliative Toxins, Toxic Shock Syndrome Toxin 1, and Methicillin Resistance. Journal of Clinical Microbiology. 2000;38:1032-5. https://doi.org/10.1128/JCM.38.3.1032-1035.2000 